See discussions, stats, and author profiles for this publication at: https://www.researchgate.net/publication/250171261

New Urbanism and nature: Green marketing and the neotraditional community

Article in Urban Geography · April 2001

DOI: 10.2747/0272-3638.22.3.220

1 author:

Karen E. Till

National University of Ireland, Maynooth

30 PUBLICATIONS 1,047 CITATIONS

SEE PROFILE

Some of the authors of this publication are also working on these related projects:

Project Wounded Cities View project 


\title{
Neotraditional towns and urban villages: the cultural production of a geography of 'otherness' ${ }^{\dagger}$
}

\author{
K Till \\ Department of Geography, University of Wisconsin-Madison, 384 Science Hall, 550 North Park Street, \\ Madison, WI 53706, USA
}

Received 21 December 1992; in revised form 13 April 1993

\begin{abstract}
The 'neotraditional' planning movement in the USA is criticized through an analysis of promotional materials for the urban village of Rancho Santa Margarita in Orange County, CA. The 'traditions' of towns and villages are viewed as recent 'inventions' created by corporate planners; they are attempts to validate the establishment of residential communities through ambiguous, yet familiar, historical symbols. Yet the identities constructed for neotraditional towns and urban villages make sense only in relation to the 'other'. In southern Orange County, corporate planners present their master-planned communities as 'distant' from the suburbs and cities located in Los Angeles and in northern Orange County according to a scale of temporal, geographic, and social values. Implicit to neotraditionalism is a geography of otherness. This geography reinforces existing social and spatial divisions, promotes reactionary and exclusionary territorial identities, and legitimizes the status quo.
\end{abstract}

\section{Introduction}

In the May/June 1992 issue of Utne Reader, a series of articles reprinted from the alternative press examined a new trend in American town planning called 'neotraditionalism' (see Bressi, 1992; Duany and Plater-Zyberk, 1992; Gerloff, 1992; Lowe, 1992). The articles, like those that have appeared in other periodicals, including Atlantic Monthly (see Langdon, 1988) and People Weekly (1990), acclaim "The neo-traditional revolution: a new generation of town planners attack the suburban status quo" (Bressi, 1992, page 101). Other magazines, such as Planning, have presented the movement in religious terms: the leaders of the movement have "visions", "spread the gospel", "preach" about the "new article(s) of faith", and denounce the "litany of suburban sins" such as Euclidean zoning (Knack, 1989)(1). What is surprising, and even disturbing, about these articles is that they neglect to question the rhetoric of 'tradition' used by these planners, architects, and developers.

A cursory look at the literature describing this trend suggests that neotraditionalists are reevaluating the nature of residential and urban spaces by adopting a more qualitative approach to the construction of planned communities. Neotraditional town planning is described as a revolt against the "meandering streets of look-alike houses" in American suburbs (Burrows, 1989, page 1). Suburban developments, which in 1990 housed almost half of America's population, are criticized as socially alienating, geographically dispersed, and environmentally harmful. "We can expect greater environmental woes and increased social fragmentation as more and more people are absorbed into the suburban lifestyle of driving all over the place all the time" (Gerloff, 1992, page 93).

† This essay is based largely upon research conducted for an unpublished masters thesis, "Expert conceptions of place and community: the planners' vision of Rancho Santa Margarita" (Till, 1991).

(1) An article by Knack (1989) was titled "Repent, ye sinners, repent"; also, one 'convert' to neotraditionalism claims to have left a seminar feeling like a "born-again planner" (Smith, 1989). 
The advocates of the new "Main and Elm Street school of urban planning" claim to offer a better alternative to the "cancerous growth" of suburban sprawl: towns and villages which have "vernacular architecture-commonplace buildings of the past, embodying folk wisdom about design and construction" (Burrows, 1989, page 1; Duany and Plater-Zyberk, 1992, page 97; Langdon, 1988, page 46). These planners assert that, unlike their predecessors, they pay attention to the unique nature of places; to their local histories, architectures, and urban and residential forms; and to traditional human-land relationships. They maintain that their towns and villages are "good places to live", places that can "revive public life", and return the "bonds of authentic community" to American society (Knack, 1989; Langdon, 1988).

A closer look at this literature, however, reveals that the so-called tradition used in the neotraditional movement is, to use Hobsbawm and Ranger's (1983) words, largely "invented". The evocation of 'tradition' through mass media can be seen as an attempt to validate the establishment of a residential community by providing a sense of historical continuity and stability. These traditions are created by corporate planners in order to give the place a sense of identity.

Identity, however, is not only a question of time but also of space. A neotraditional town or village is described as a 'good' place by these planners, and situated as distant from other places, such as suburbs, according to a skewed scale of temporal, geographic, and social values. Implicit in the neotraditionalists' claim to the past, therefore, is a geography of 'otherness'-a constructed hierarchy of place which legitimizes territorial boundaries and regional identities as being normal.

I explore these themes through an analysis of an urban village in Orange County, CA, called Rancho Santa Margarita.(2) First I outline two examples of the 'traditions' at Rancho Santa Margarita, the community's "family history" and its "early California Spanish colonial" architecture, as presented in promotional materials. By paying particular attention to Hobsbawm's concept of 'invented tradition', I criticize the use of 'history' at Rancho Santa Margarita and for neotraditional towns in general. I examine the social implications of the process of 'inventing traditions'; examples within the regional, popular cultural context of Orange County are given to illustrate the intended impact of advertisements for Rancho Santa Margarita on potential buyers. By way of conclusion, I situate the significance of the movement and its 'traditions' within the context of the professional planning community.

The promotional materials for my analysis include: advertisements and articles in local newspapers and magazines; brochures, maps, and newsletters available at the Rancho Santa Margarita Information Center; press releases; and press clippings. I attempt to combine qualitative (semiotic) and quantitative (content analysis) approaches to analyze these texts, with an emphasis on the former-a methodology that is "rigorous and systematic while also being sensitive to the multiple levels of meaning and the multiple codes that ads employ" (Leiss and Jhally, 1986, page 175; see also Williamson, 1978). In addition, I rely upon information obtained from interviews with several Orange County developers, planners, and government officials. Because the Santa Margarita Company (the urban village corporate developers and master planners) declined several requests for an interview, ${ }^{(3)}$ some information

(2) Although promotional materials do not explicitly identify Rancho Santa Margarita as a 'neotraditional' town, planning journals and the Urban Land Institute have described it as a 'new town'. In planning circles and in the literature about neotraditionalist projects, the terms 'urban village', 'new town', and 'village' are often used interchangeably.

(3) Santa Margarita Company Public Directions director Diane Gaynor explained that the Company was "working from a skeleton staff" and did not have time for interviews because of budget cutbacks. She did, however, send me newspaper articles and other public-relations material about affordable housing in Orange County (see Till, 1991). 
about the Rancho Santa Margarita planning concept comes from lengthy interviews I conducted with two Senior Vice Presidents from Phillips, Brandt and Reddick (PBR). The Santa Margarita Company subcontracted PBR to help develop the product concept of the urban village, as well as to help design, market, and entitle Rancho Santa Margarita. ${ }^{(4)}$

\section{Invented traditions}

According to Hobsbawm (1983), invented traditions are sets of practices that are created to impart certain values and social norms. These traditions "attempt to establish continuity with a suitable past" (Hobsbawm, 1983, page 1) through the creation of rituals and rules, through the use of historically loaded symbols, or simply through repetition, which implies a connection with the past. As many of these traditions are quite recent in origin and are often invented, Hobsbawm considers the study of their appearance and establishment, rather than of their longevity, to be most significant. In short, the invention of traditions is the process of creating symbolic complexes that provide a sense of continuity with a largely fictitious past.

Hobsbawm goes on to outline three interrelated types of invented tradition: those that establish or symbolize social cohesion to and/or membership of real or artificial communities, those that legitimize institutions, and those that impart value systems. He suggests that the first type is the most prevalent, and that the other two are often implicit in a sense of identification with a 'community' and/or the institutions that represent the community. Hobsbawm makes clear, however, that the communities under consideration are modern; "the contrast between the constant change and innovation of the modern world and the attempt to structure at least some parts of social life within it as unchanging and invariant makes the process of 'inventing tradition' so interesting" (Hobsbawm, 1983, page 2). Unlike the rites of passage and customs of "traditional societies", he argues, the invented practices of the modern pseudocommunity (such as the all-encompassing nationstate) tend to be "quite unspecific and vague as to the nature of the values, rights and obligations of the group membership they inculcate" (Hobsbawm, 1983, page 10).(5) This latter point is an important one. Hobsbawm argues that the identification of the invention of these symbolically charged (yet undefined and universal) signs of membership provides us with significant data about social problems that may be otherwise difficult to recognize (other authors have dealt with similar themes, for example, Hunt, 1989; Lipsitz, 1990; Silverman, 1986).

The study of invented tradition not only offers us evidence of societal developments, it also illuminates the contradictions inherent in the establishment of pseudomodern communities. Although new, these communities are represented as being so 'rooted' in the past that their existence appears to be 'natural' (Hobsbawm, 1983). In this

(4) Although planners, architects, and developers may have different cultural presuppositions, and may not share the same set of economic and political imperatives, the distinctions between what these experts actually do (their terrain of expertise) appears to have become somewhat fuzzy in recent years. For example, the best known neotraditional town planners are Andres Duany and Elizabeth Plater-Zyberk, architects based in Miami, FL. Or, for example, Peter Brown of the Houston-based architecture firm EDI was hired by the developer Robert Tuschak to plan the neotraditional town of Montgomery Village, NJ. For Rancho Santa Margarita, the master planner is also the corporate developer, who, in turn, subcontracts smaller firms (planners, architects, developers, builders, and so on) to help produce the master-planned community. Consequently, I have not clearly distinguished the corporate planner from the corporate developer in this paper, which may present problems, but is another topic for future discussion.

(5) Hobsbawm distinguishes between 'custom' (in traditional societies) and invented tradition' (in modern societies). As recent work in anthropology illustrates, these distinctions may not be so clear cut (for example, see Clifford, 1988; Clifford and Marcus, 1986). 
light, and importantly for geographers, the attempt to establish continuity with a 'suitable past' often includes the making and remaking of places, such as museums and memorials, or neotraditional towns and urban villages. The study of invented traditions, then, is implicitly-if not explicitly-geographic in nature. Moreover, it may help explain recent attempts by individuals and groups to recapture a sense of 'rootedness' and to restore a 'sense of place' to modern Western society through the construction of symbolic geographic complexes (for a discussion of "rootedness versus sense of place", see Tuan, 1980; also, see Dorst, 1989; Lipsitz, 1990; Lowenthal, 1985; Sack, 1988). From this cultural geographic perspective, I now turn to a description of the signs of membership found in the urban village of Rancho Santa Margarita.

\subsection{The 'family heritage' at Rancho Santa Margarita}

Rancho Santa Margarita is a master-planned community in Orange County and is expected to be completed by the year 2015 (figure 1). Advertised as the 'Town For Life', it is presented as an 'urban village'-a community which offers the amenities of a small city and a small town. In contrast to the suburbs, resort areas, and large cities of southern California, Rancho Santa Margarita is depicted as a unique place that will meet the needs of individuals through a "community design at the

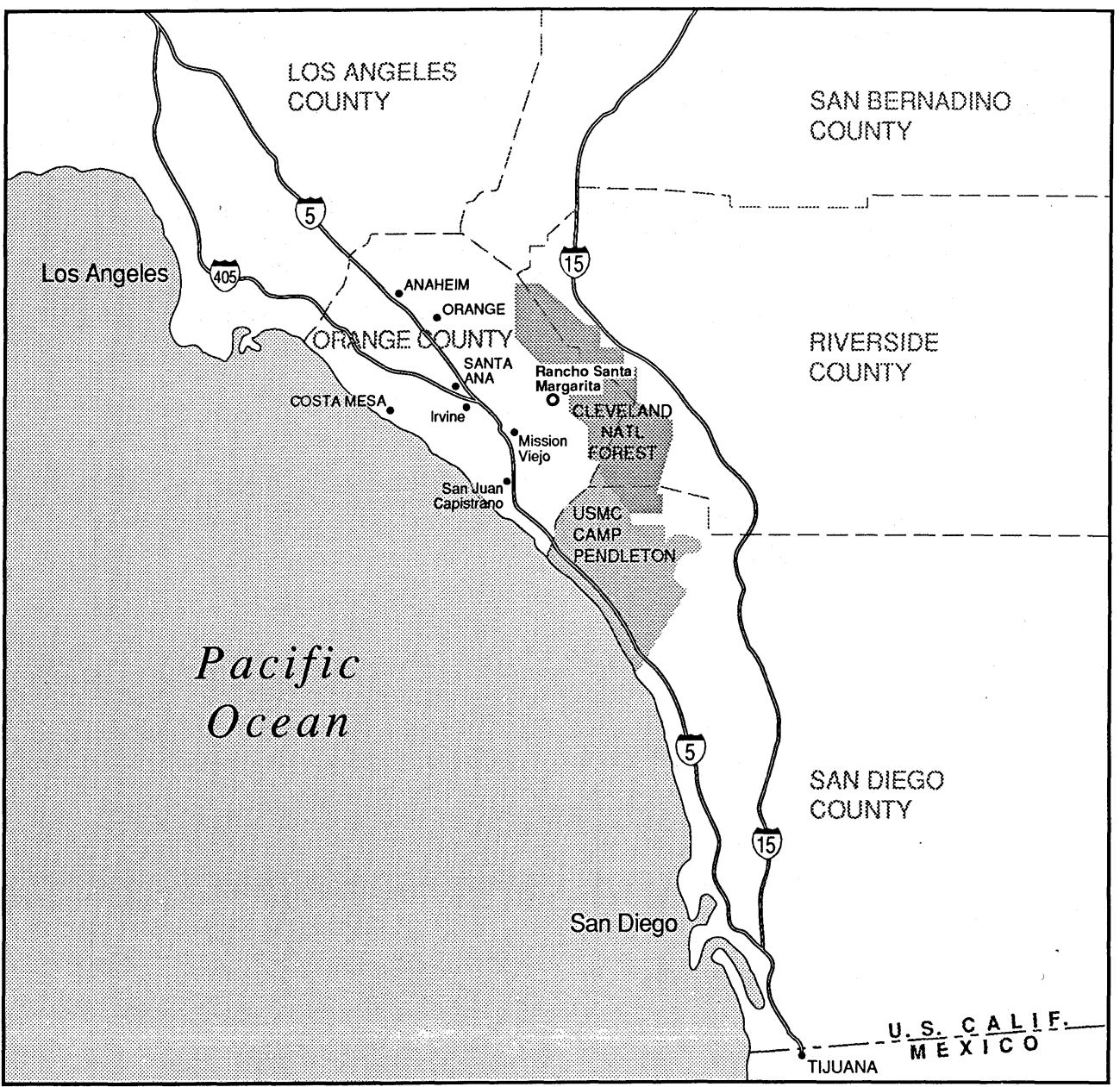

Figure 1. Location map for Rancho Santa Margarita. 
relationship level not just at the real-estate level" (interview with S Kellenburg, Senior Vice President, PBR, November 1989). This feeling of community is thought to be achieved in part through the 'traditions' at Rancho Santa Margarita, which, according to promotional materials, include the community's "family history" and the "early Californian Spanish colonial" architecture.

According to the urban village promotional materials, the current landowners of Rancho Santa Margarita are descendants of this historic landowning O'Neill family. Consequently, the present-day development company, the Santa Margarita Company, claims that they have the responsibility to "keep alive the [frontier] traditions of the past. And to carry out the vision of our people today" (Santa Margarita Company, 1989a, inside cover). The legacy of the O'Neill family-described in 'historical newsletters' published by the Santa Margarita Company-is presented as evidence that the development company-family will continue the tradition of 'caring for the land'.

The textured and tan pages of these newsletters, which are printed with brown ink and Western-style fonts, state that the family history begins in 1882 when the family patriarch, Richard O'Neill, saw the ranch, tamed the wild lands, and made them productive (figure 2). ${ }^{(6)}$

"Sizing up the ranch was a banty-legged Irish cattleman ... Born in Brigown

Parish, County Cork, in the heart of Ireland's dairy country, he had traveled far in his fifty-seven years and missed several fortunes in the process. O'Neill vowed not to miss another. Somehow, the sight of Santa Margarita's slat-sided cows dining on parched stubble reminded him of his own odyssey" (Santa Margarita Company, 1985, pages 1-2).

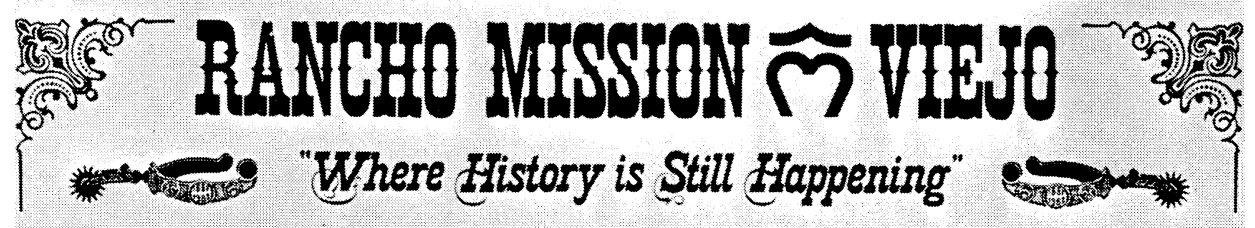

SPECIAL. RANCHO SANTA MARGARITA EDITION

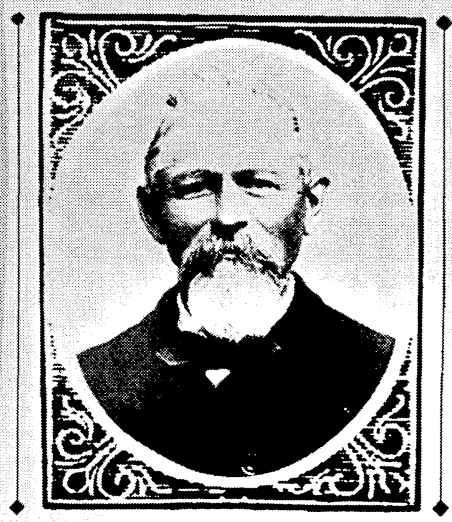

RICHARD O'NEILL. $1825-1910$

Figure 2. Richard O’Neill Sr, the Rancho Santa Margarita patriarch (Santa Margarita Company, 1992, page 1).

(6) Unless otherwise cited, the material for this section comes from one historical newsletter with the heading Rancho Mission Viejo: Where History is Still Happening (Santa Margarita Company, 1985, pages 1-4). 
After working hard for twenty-five years and living in an adobe ranch house, O'Neill acquired full title to half the ranch. He imported Texas shorthorns, put in feed lots and crops, "waged war on squatters and wild hogs in the San Mateo", leased out Trabuco Mesa to see it become Orange County's "biggest wheat field", and welcomed the arrival of the Santa Fe Railroad line. In addition to being a hard worker and good businessman, O'Neill is also presented as being socially

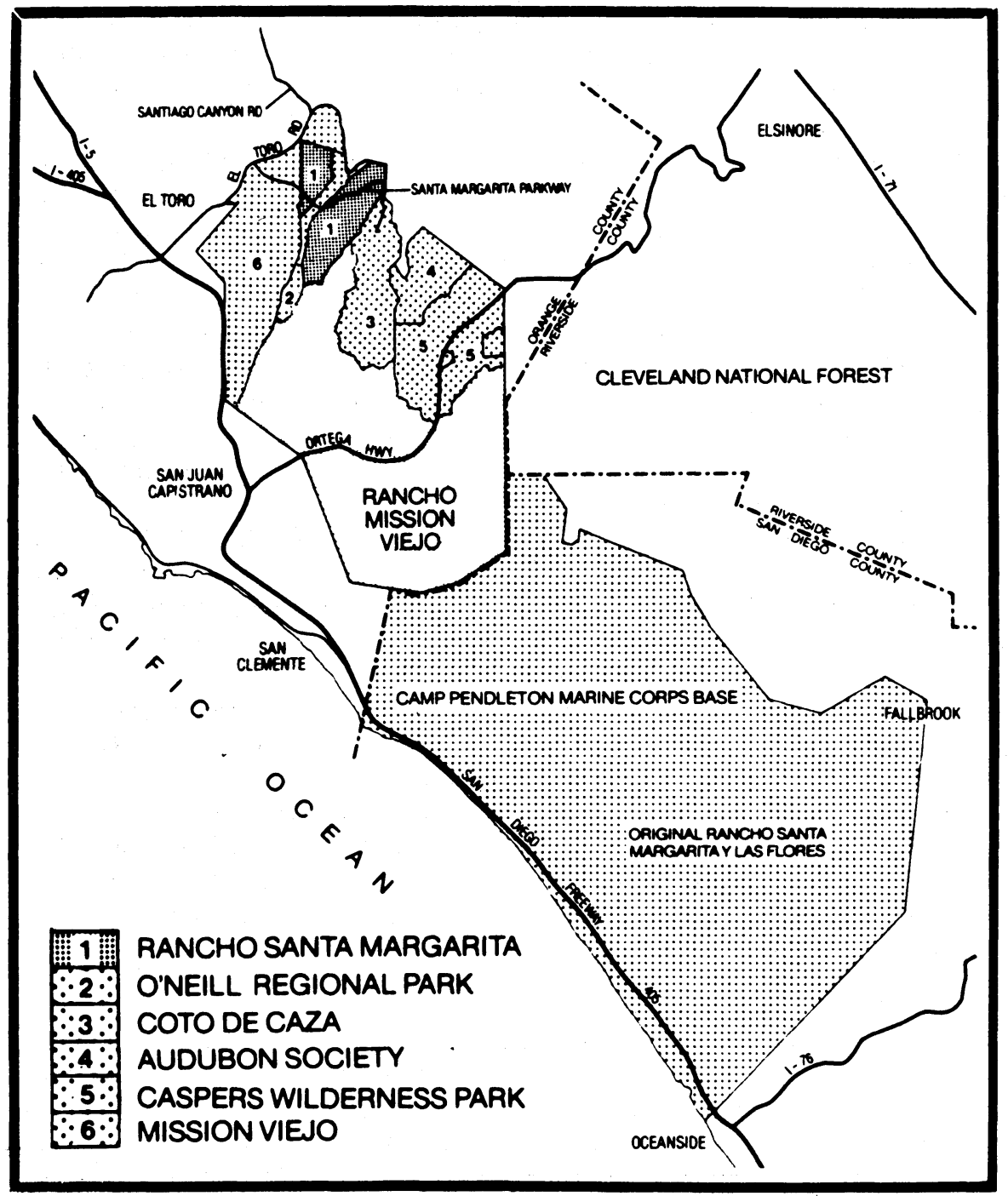

\section{Under Richard O'Neill, Rancho Santa Margarita}

(359 square miles) stretched from Oceanside to Aliso Creek. Name is being revived in current Rancho Santa Margarita development.

Figure 3. 'Historic' map of Rancho Santa Margarita and neighboring ranches (Santa Margarita Company, 1992, page 1). 
responsible: he donated three acres to start the first local school, which later served as a church, civic center, social hall, polling place, and post office (Santa Margarita Company, 1986a).

In 1909 Richard O'Neill's son Jerome (described as "a sharp planner and shrewd poker-player" in one newsletter) became the next property manager. Under his management, the ranch reached its greatest areal extent, including land in currentday San Diego County. In 1940, however, the lands were divided: Jerome's son, Richard O'Neill Jr, "by luck or foresight" took the northern Orange County lands, and later, during World War 2, the US Marine Corps took the entire San Diego property for the Camp Joseph $\mathrm{H}$ Pendleton military base. "What remained of the historic Santa Margarita became known as the Rancho Mission Viejo-much reduced, but still a substantial 52,000 acres" (figure 3).

Richard O'Neill Jr died in 1943, leaving the lands to his widow Marguerite and their children Alice and Richard Jerome O'Neill. The newsletters explain that the lands remained "unchanged" until the 1960 s, when "Orange County's population explosion forced the ranch to modify its pastoral ways". The first residential venture on the ranch was the 10000 acre planned community of Mission Viejo (built in 1960, and sold to Philip Morris Inc. in 1972). In 1981, Marguerite O'Neill Jr died, thereby ending Jerome O'Neill's Trust and allowing her son Richard Jerome to zone the Trust area to be used for the present-day Rancho Santa Margarita. The O'Neill family heirs, still the owners of the 'historic' Rancho Mission Viejo, formed the San Juan Company (25000 acres) and the Santa Margarita Company (15000 acres) in 1983 (Santa Margarita Company, 1989).

Today, Richard Jerome O'Neill is the Chairman of the Santa Margarita Company, and Anthony Moiso, the great grandson of Richard O'Neill, is the Chief Executive Officer and President of the Santa Margarita Company. According to promotional materials, the family heirs have followed the ideals of the family patriarch Richard O'Neill, a tradition "passed down through four generations":

"the O'Neills have met their civic commitments with generous land donations for roads, schools and parks, and made personal ones to such things as the Old Mission's restoration and museums for local history.

Moreover, the ranch has retained its 200-year heritage by hosting such events as El Viaje de Portolá, spring round-ups and annual fandangos. Most importantly, the family has kept faith with its founder. Today, the ranch remains the last large-scale cattle operation in southern California" (Santa Margarita Company, 1985, page 4).

\section{2 'Preserving' the traditional through contemporary landscapes}

A second way in which a historical tradition is said to exist at Rancho Santa Margarita is through the 'preservation' of early Californian Spanish colonial architecture and 'traditional' human-land relationships in the urban village landscape (figure 4).

"The architecture of Rancho Santa Margarita goes back to this early [Californian] tradition. And beyond, when 18th century Spanish missionaries built California's first churches, missions, and monasteries.

Today, many of these architectural elements from the past are being preserved in the homes and public buildings of Rancho Santa Margarita" (Santa Margarita Company, 1988, page 9).

Some of these architectural elements include: clay-tiled roofs ("part of the town's Spanish origins"), stucco walls "in warm hues and inlaid tiles [which] also speak of Early California”, and rounded archways (Santa Margarita Company, 1988, page 9).(7)

(7) The remaining information in this paragraph comes from Santa Margarita Company (1988, page 9). 
The bells in the urban village, "echoing down through the centuries ... in towers like those first seen in Spain", are said to have been historically located in places where all the community facilities could be found. Today, "thematic" bell towers, as well as palm trees and water features ("another borrowing from the Old World: fountains") are located at the community's "people-oriented places". ${ }^{(8)}$

The human-land relationships outlined in Rancho Santa Margarita's master plan are also considered to be part of an 'early Californian tradition':

"When settlers first opened up the West, the land dictated a whole new kind of architecture. One that brought breathtaking views of its canyons, its plains and its coastal mountains into the daily lives of the people.

So their houses were built with porches. And their porches became their living rooms. The place to rest and relax, to take it all in. Indoors was reserved for sleeping ... cooking. And the outdoor/indoor philosophy became a fundamental motif of western architecture" (Santa Margarita Company, 1988, page 9). According to one planner, shade was important to the past villagers because of the harsh desert climate: in order to obtain cooler, shady environments, villagers manipulated indoor-outdoor spatial relations (interview with S Kellenburg, Senior Vice President, PBR, November 1989). Today, this 'philosophy' is said to be replicated in the plazas, patios, balconies, overhangs, and eves: "patios (the inner courtyards of the Past) provide privacy and easy indoor-outdoor living", and "part of the great outdoors" can be enjoyed through "a balcony at day's end" (Santa

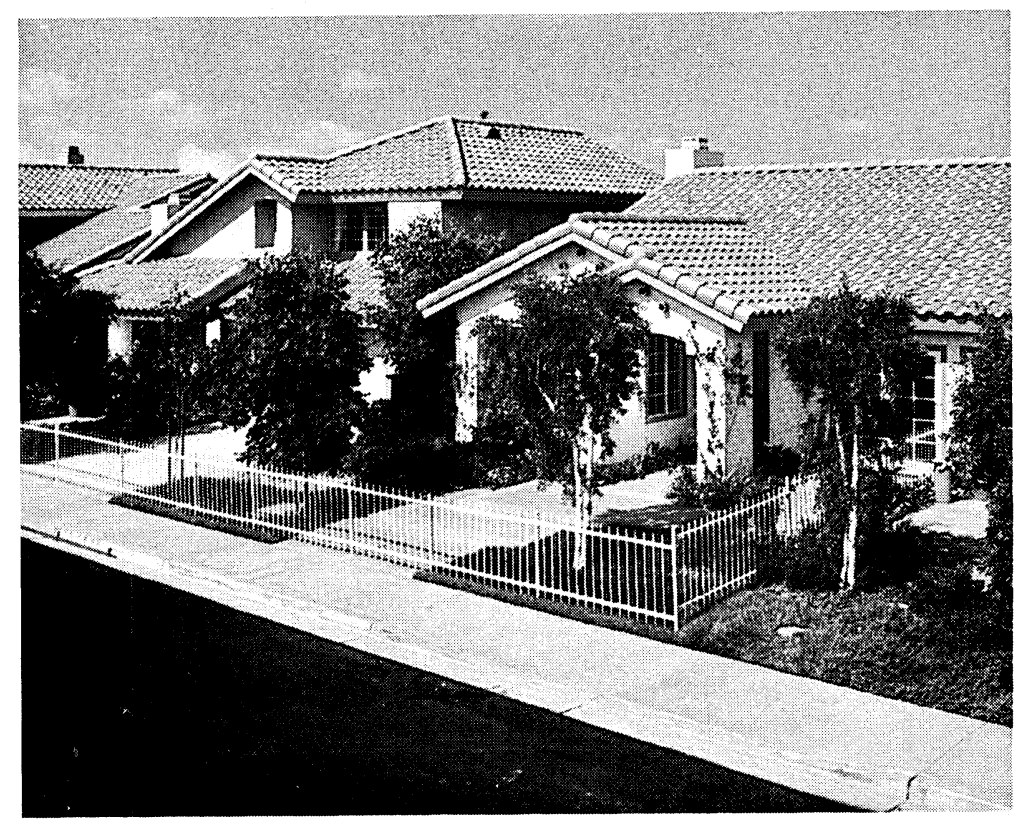

Figure 4. "Architecture, alive with the past ... and the present": "detached homes come in a wide range of styles and floor plans-for young or growing families. Or people with a taste for space" (Santa Margarita Company, 1991, page 10).

(8) "People-oriented places" at Rancho Santa Margarita are described as the community's "outdoor living rooms". They include parks, a town center, a constructed lake and beach club, a golf course, and other recreational areas. "Thematic" bell towers are described as aesthetic elements located at all the people-oriented places (interview with S Kellenburg, Senior Vice President, PBR, November 1989; interview with M Horst, Senior Vice President, PBR, March 1990). 
Margarita Company, 1988, page 9). These 'traditional' design features, as well as the 'preserved' early Californian Spanish colonial architecture at Rancho Santa Margarita, are thought to create "an enhanced historical setting" which imparts "the feeling of a European, traditional model of community" to visitors and residents of the urban village (interview with S Kellenburg, Senior Vice President, PBR, November 1989).

\subsection{A 'traditional' community?}

From this brief sampling of the 'traditions' described in the promotional materials of Rancho Santa Margarita, it is clear that the Orange County urban village's 'suitable past' is a popularized, commercialized (and hence familiar) compilation of various myths and symbols about the heroic American West. For example, the format of the O'Neill story is similar to the fictional past found in the American Western novel genre (for interpretations of the American Western novel, see Boatright, 1957; Tatum, 1988; Wright, 1975). Typical of the cowboy hero in Western novels, Richard O'Neill Senior, a white European immigrant, helps "tame the wild forces" and guarantees a democratic society in the (Orange County) West. As an outsider and wanderer, he is first associated with the frontier and identifies with the animals, the "slat-sided cows". After turning desolate lands into productive fields, O'Neill is recognized by the local community for his special talents: he keeps these lands safe for social order by waging war on wild animals and squatters (Native Americans? Mexicans? African-Americans? Chinese?), and supports the establishment of railroads, which symbolizes the arrival of (European) 'civilization' to the savage frontier. Although O'Neill's heirs are not presented as strongly in this cowboy-hero characterization, they have kept the lands through astute corporate action. O'Neill men are the "professional" cowboys of the "last large-scale cattle operation" in the Orange Country "frontier". (9) Indeed, in the newsletters, one finds photographs of great-grandson Anthony 'Tony' Moiso atop his trusty horse; he is depicted as "equally adept behind a saddle horn or desk" (Santa Margarita Company, 1985, page 4).

The O'Neill genealogy highlights the 'historic' role of the Santa Margarita Company as the inevitable and 'natural' caretakers of the present and future 'ranch':

"As a new century approaches, having enjoyed 11 decades of successful ranch management, the O'Neill family reaffirms the pledge to build for a better future while preserving the best of an ever-colorful past" (Santa Margarita Company, 1992, page 4).

This advertised family story also legitimizes the authority of the Santa Margarita Company as the experts who decide what constitutes "an ever-colorful past" and a "better future". An important part of the O'Neill past and future is the promotion of a singular perspective (white European landowning male), which is assumed to be shared by potential homebuyers. Consumers are asked to identify with the past and present patriarchs of the great ranch, and with their European ideals of community. Their heroic tales and the cultural symbols associated with them (such as the cowboy) are so strongly associated with other myths such as 'Westward expansion' and the 'American dream' that there is little room left for stories from the perspectives of other individuals, including those of women, children, and/or

(9) Wright (1975) uses the term "professional" cowboy to describe characters in a type of Western which differ from those in a classic Western. In the classic version, the estranged cowboy saves society and tames the frontier. In the professional Western, there exists a group of cowboys-professionals or experts in a 'technocratic' society-who are bound together because of their profession. 
gays from various cultural, ethnic, and socioeconomic backgrounds. For example, the only female in the O'Neill story is described in terms of her European ancestry and ability to reproduce: "A descendant of Spanish stock which arrived in California in 1781, Marguerite also brought Rancho Mission Viejo's heritage full circle" (Santa Margarita Company, 1992, page 4). Thus, the promotion of a narrow perspectiveone which attempts to silence alternative readings and interpretations of familiar texts and symbols-not only enhances the status of the corporate planners as the community 'experts' who construct 'good places to live', it also imparts social values.

These texts which promote historical continuity with a 'suitable past' can be considered an example of what Dorst (1989) calls 'traditionalization', the production of historical 'authenticity' as a consumable image. History becomes a spectacle: it is selectively arranged by neotraditionalists to validate what appears to be an historically authentic community. As Dorst (1989, page 16) notes, "the production and reproduction of texts about stability, completeness, and continuity in the face of patent historical diversity, discontinuity, and drastic selectivity is important for reading the Site". These texts are by no means limited to histories, but include images as well as landscapes. At Rancho Santa Margarita, the 'preserved' architecture of the urban village creates the illusion that the place is historically 'authentic'.

The built environment of the urban village tangibly promotes a sense of historical completeness in architecture and design, even though the 'early Californian Spanish colonial tradition' is a highly selective one. In fact, the contemporary architectural styles found in many southern Californian planned communities are idealized re-reinterpretations of upper-class 19 th-century romantic imaginings of 17 th-century missions. ${ }^{(10)}$ The 'preserved' landscapes at Rancho Santa Margarita are mass-produced units built by large Californian building companies. They are designed to resemble the built environments of the already established elite communities in southern California (for example, Santa Barbara or Carmel). Of course, these builders are not historic preservationists who attempt to reconstruct the mission buildings by using the same techniques and materials that were employed in the 18 th-century. Rather, their buildings are constructed for specific regional markets whose consumers are familiar with (and most likely expect) this style which symbolizes the exclusiveness of middle-class and upper-class residential communities. Similarly, the design features of the "indoor/outdoor philosophy" better reflect contemporary product differentiation and marketing strategies than the techniques pursued by 'traditional' villagers to manipulate the environments of their day. Instead of using a balcony or patio, most contemporary village residents turn on their air-conditioners to temper the chaparral climate of the great outdoors.

The selective use of popularized myths and ambiguous regional symbols is by no means unique to Rancho Santa Margarita. Design guidelines for neotraditional towns also connote a sense of temporal continuity and authenticity through familiar, yet vague, historical visual references and family stories. For example, a proposed "rural villages ordinance" for Loudoun County in Virginia, stipulates a "loose grid network surrounding a village green in the style of Leesburg and other historic Virginia towns" (Knack, 1989, page 9). The design guidelines for Seaside, FL, perhaps the best known neotraditional town, require "wood-shingled, clapboard,

(10) The romanticized view of California's past in late-19th-century writings led to the restoration of missions and to the emergence of a new architectural style. In the 1920s, a 'newer' revivalist style of Spanish colonial architecture evolved in Santa Barbara and in southern California which lacked the highly decorative facades of the Spanish Churriguereque style of 17 th-century and 18 th-century buildings. In the early 1960 s there was another mission revivalism (called 'early California, Spanish colonial' architecture), whose forms were based largely upon cities such as Santa Barbara (Morris, 1989). 
and board-and-batten houses with deep front porches and shiny tin roofs like those on old houses in rural America. Cupolas and towers rise from some roofs, giving the skyline a picturesque, almost whimsical air. The houses' windows follow the proportions of eighty to a hundred years ago-predominantly tall and narrow" (Langdon, 1988, page 39). Although neotraditional town planners claim their designs stem from actual turn-of-the-century American towns from specific regions, as these examples show, their plans reflect a profound lack of historical specificity. Rather, neotraditionalists create idealized images which harken back to an ambiguous past based on the tastes of particular regional markets.

Not only are the so-called 'traditional design guidelines' recent inventions, but the 'histories' which accompany them are also fabricated. For example, in order to make Montgomery Village, NJ, "a town that seems to have a past" the developer and planner-architect "invented a 'fictional history' and new site plans of the village as it would have been in various historical epochs" (Knack, 1989, page 12, emphasis added).(11) Buildings are designed "to look like historic buildings converted to new uses-mansions converted to condos, for example" and a family history has even been invented to authenticate these site plans. The fictional scenario describes a Dutch family which settled in current-day Somerset County, NJ. The family worked hard to build a thriving farm, and "as the family prospered, so did the area". Other families and businesses moved to the area and flourished; "over the next two centuries, the area grew to become today's Montgomery Village".

At Rancho Santa Margarita and for neotraditional towns such as Seaside and Montgomery Village, the advertisements, designs, and built environments-all of which refer back to a vague yet 'suitable' small-town past-can be seen as attempts to establish community identity. The communication of these ambiguous symbols in promotional materials is made possible through mass-communication technologies. According to Lipsitz (1990, page 5), "Time, history, and memory become qualitatively different concepts in a world where electronic mass communication is possible. Instead of relating to the past through a shared sense of ancestry, consumers of electronic mass media can experience a common heritage with people they have never seen; they can acquire memories of a past to which they have no geographic or biological connection". The genres of the stories, the brown-and-white photos in the 'historical newsletters', and the 'preserved' architecture and design are intended to create a popular and familiar image of something from the past, even though it is not clear what the connection is between current-day homeowners and these 'past' peoples and places. These texts suggest that by buying a unit in a neotraditional town or urban village, a homeowner will inherit a family history, an historic landscape, and the exclusive membership rights of an 'authentic' planned residential community.

At the macroscale it appears that neotraditionalists have invented similar traditions ('family histories' and 'authentic' landscapes) to establish a sense of community identity, regardless of where the town or village is located. But at the local scale, they have selected regional (albeit vague) images, narratives, and built environments which are targeted toward specific market clusters to establish a sense of social cohesion. ${ }^{(12)}$ And yet this vagueness is precisely the point. According to Hobsbawm (1983), such undefined yet symbolically powerful signs of community membership are indicators of social problems which might not be otherwise identified. As I argue in the next

(11) The remaining information about Montgomery Village in this paragraph comes from Knack (1989, page 12).

(12) As Leslie (1992) points out in her discussion of "Advertising, femininity and place", advertisers have responded to the waning of the mass-market-consumption household of Fordism by using ambiguity or multiple advertisements to appeal to increasingly fragmented market segments. Also, see Sack (1988), and section 3.3 of this paper. 
section, the invented traditions described above not only promote a sense of community identity and lend credibility to the neotraditionalist as expert, they also reflect existing social values. The regional marketing strategies employed by neotraditionalists promote an exclusionary sense of territorial identity based upon those values.

\section{Neotraditional towns and the 'other'}

As suggested earlier, neotraditionalists create a hierarchy of place through the establishment of a hierarchy of social values (see Stallybrass and White, 1986). Their 'authentic' town or village is situated as the 'high' (good) in contrast to the 'low' (bad) places such as the suburb or city. These categories of high and low, of good and bad, are constructed in terms of time and space. According to Fabian (1983), time and space are carriers of significance, a means by which people define the relations between themselves and others; in constituting the 'other', one creates an object which is distanced from the self in time and in space. Thus, implicit to the neotraditional texts about historical stability and continuity is a geography of 'otherness'. Within a regional context, the small-town image presented in advertisements for Rancho Santa Margarita makes sense only in relation to images of the distant 'other', which in Orange County means Los Angeles (figure 5).

\subsection{Temporal distance: the Orange County past}

I have already provided examples of how the Santa Margarita Company has created familiar, historical texts and images in order to provide a sense of identity for the planned community. Yet these claims to authenticity take on specific meanings in the context of Orange County's folklore and popular history. In general, Orange County is presented metaphorically as a small town that has grown politically, morally, and socially distant from the City and County of Los Angeles.

According to the most recent versions of Orange County folklore, people living in what was southeast Los Angeles County in the 1880 s wanted local autonomy. ${ }^{(13)}$ They believed they were 'oppressed' within Los Angeles' legal system and felt as though they had to pay taxes for 'urban' problems that were not their own; "the more hectic life of the emerging metropolis had little they wanted as compensation" (Scheer, 1989a, page 27). So, in 1889, Santa Ana merchants and farmers bribed LA and Californian officials to pass a bill so that Orange County could secede from Los Angeles (Santa Margarita Company, 1986a; Scheer, 1989a). In the words of Santa Ana grocery storeowner George Edgar, "Hell yes, we bought this county from the state Legislature for \$10,000" (Wieman, 1939, quoted in Scheer, 1989a, page 26). The people living on the lands where Rancho Santa Margarita now stands are said to have played an important role in the county's history. According to the planned community's "historical newsletters", the people of the Trabuco Oaks community unanimously voted for the new county of Orange in 1889. These 'pioneers' were given a flag and thanked by the new administrators of Orange County for their "united effort ... to free us from the bondage of imperialism and the many burdens incident to our connection with Los Angeles county" (Santa Margarita Company, 1986a, page 2).

The stories not explicitly recounted in the Orange County histories, however, are those which depict an emerging provincialism and "desire to avoid the turbulence of the larger American culture by excluding the nation's 'problems' and 'problem groups'” (Scheer, 1989a, page 27). The strong presence of Ku Klux Klan members 
in Anaheim's police force and in elected municipal positions during the $1920 \mathrm{~s}$, the massive migration of conservative, white, middle-class individuals to Orange County from Los Angeles in the 1950s and 1960s, and the emergence of the postwar ultraconservative John Birch Society during the 1950s and 1960s are downplayed or not mentioned at all. [Interestingly, but not surprisingly, these events found

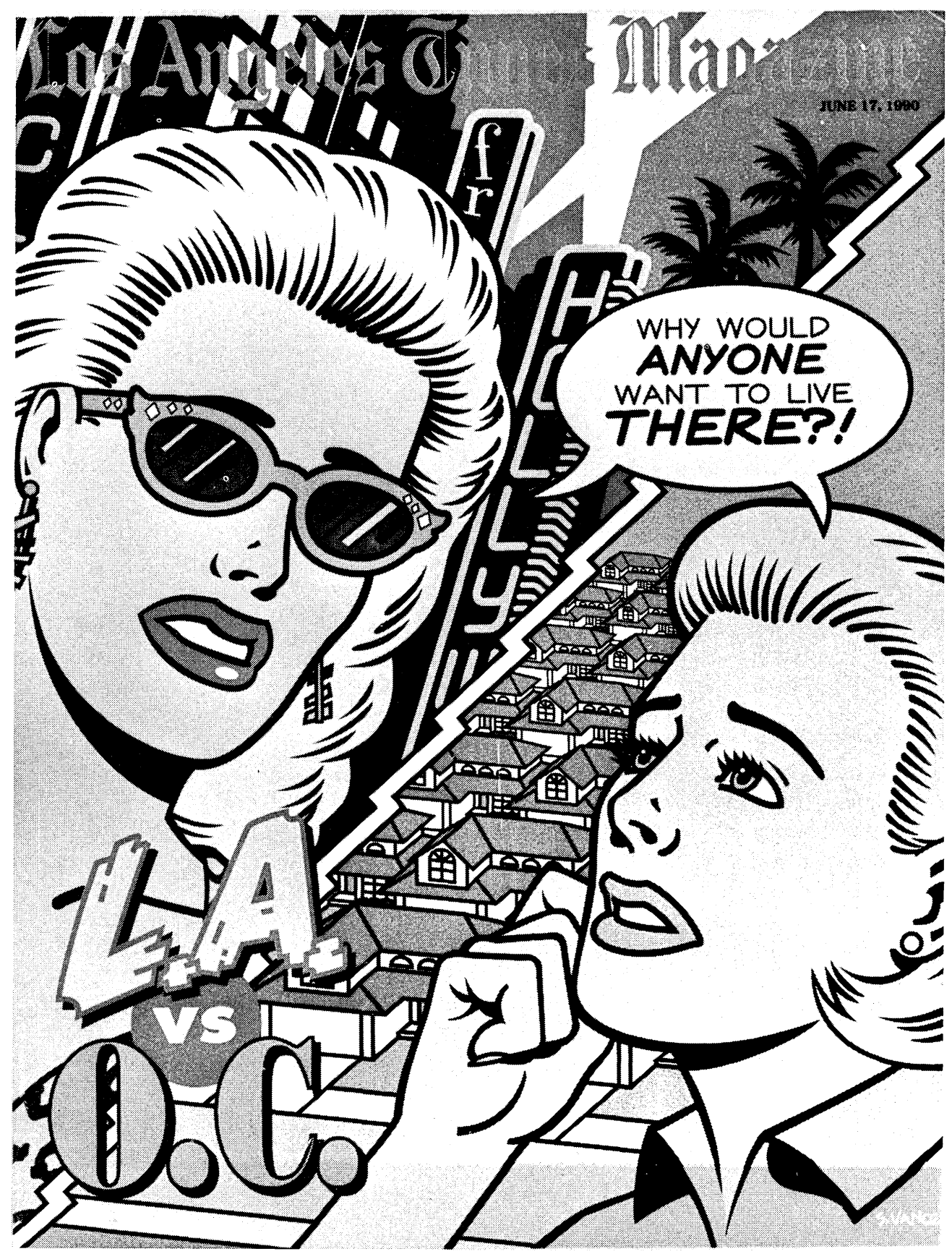

rigure 5. Los Angeles as the 'other' (artwork by S Vance, 1990; cover illustration of Los Angeles Times Magazine 17 July). 
their way into coverage by The Los Angeles Times of Orange County's Centennial celebration in 1989 (see Scheer, 1989a; 1989b).]

\subsection{Place memory}

Rancho Santa Margarita is not only depicted as distant from Los Angeles in the Orange County past, but also seen as a new and better kind of place for the future. In local newspapers, the planned community's small-town identity is situated within the history and future of Orange County. "While developers see Rancho Santa Margarita as a planned community of the future, residents there now make it sound more like a small town out of the 1950 s, like Orange County in the post-war years, full of new homes, new families, and new friends" (Clifford, 1989b, page A1). This blending of past, present, and future images are described by Perlman (1988, page 37) as "remembering the future ... a form of memory in which images of the possible or anticipated future are made present in the 'past' of remembering". ${ }^{14}$ ) The narrative schemes of the Rancho Santa Margarita advertisements structure time-present and time-future in terms of time-past. The images of the postwar Orange County small town are 'remembered' in order to make a vision of the future real in the present.

"The designers of urban villages strive to evoke an era when people gathered on front porches at twilight, strolled to the park on Sunday, attended lectures and concerts in nearby town halls, lived over the stores they owned or walked a few blocks to work. Images like these, as foreign as they may seem to life in suburban Southern California, are influencing the design of neighborhoods where thousands of people will live and work by the early years of the next century" (Clifford, 1989a, page A1).

The historic small-town identity that planners would like to foster, however, makes sense only in relation to the place memory of Los Angeles. The success of the former-the small-town identity-depends upon the experience of the latter-presentday suburbs and cities. Both identities revolve around popular conceptions of current residential experiences in southern California, and both draw upon popularized 'memories' of those experiences in the past, before it became 'bad' and 'dangerous'.

Residents of these urban villages are thus distanced from life in suburbia; at Rancho Santa Margarita, for example, future homeowners are told they are "going to live a totally different lifestyle than most of the people who live out there in that suburban sprawl" (my emphasis, R Reese, Director of Planning, Santa Margarita Company, quoted in Wynns, 1989, page 5). These (middle-class) images of the suburb can be associated directly with Los Angeles in southern California, "a city with no downtown-a sprawling amoeba of unending stretches of suburban tract houses, connected by more freeways than exist anywhere else in America" (Lockwood and Leinberger, 1988, page 31). Suburbs are thought of as being spread out and far from employment and shopping centers. One must continually drive to work and consume; hence, the sprawling suburb is also equated with traffic and smog and with the negative aspects of commuting, all of which are associated with Los Angeles.

Los Angles is also presented as dangerous, corrupt, and immoral. Lockwood and Leinberger (1988, page 31 ) describe it as "an intellectually and culturally vapid city where many residents worship rampant materialism while others pursue various forms of self-realization with equally intense preoccupation". Popular images of Los Angeles present a city gone wild, a fallen paradise. Think of the recent films

(14) Perlman explains that the presence of images of the future is related to images of memory ontologically (the future can endure only through being remembered in imagination) and because it is psychologically inevitable (images of the future will have a psychological resonance with the past and present). (See also Namie, 1942). 
about contemporary Los Angeles, such as Grand Canyon, Scenes from a Mall, or L.A. Story, or of the futuristic vision presented in Blade Runner: people are always driving, getting shot at, and aimlessly wandering the streets. ${ }^{(15)}$ In these movies, it is unhealthy, even deadly, to live in a city filled with crime, pollutants, gangs, and earthquakes. The 1992 media coverage of the Los Angeles riots following the Rodney King trials in April has reinforced these Hollywood images of Los Angeles as a dark city on fire, a place where looting, chaos, and violence prevail.

Planners of Rancho Santa Margarita feel the urban-village concept is a far cry from the Los Angeles urban experience. In contrast to the images of the chaotic landscapes of Los Angeles, corporate planners advertise the orderly landscapes of a rural small town. Rancho Santa Margarita is not considered to be sprawling or out of control in the present nor expected to be in the future because of its master plan (figure 6). It is a "balanced" town where "living, working and recreation combine so naturally" (Santa Margarita Company, 1991, page 11). The urban village will house between 40000 and 50000 residents, as well as employ up to 26000 individuals. Ultimately, it will have in its town center, a Main Street, Central Park, Promenade, and Business Park. Each of the three residential enclaves will have a commercial center, day-care centers, parks, and access to churches and schools. Over 2500 acres of the planned community are designated as 'open space'.

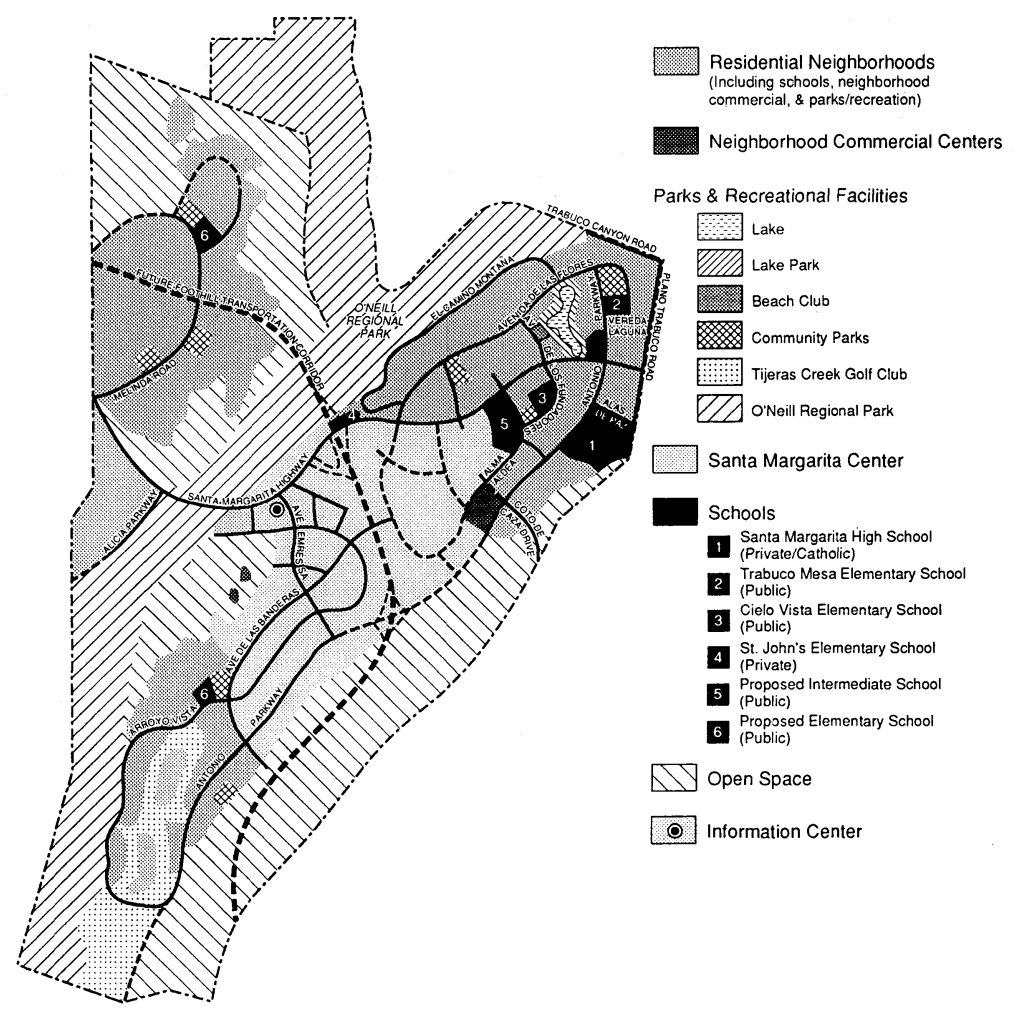

Figure 6. Land-use map for Rancho Santa Margarita: "master-planned for today ... and tomorrow" (Santa Margarita Company, 1991, page 11).

(15) These visions of Los Angeles are similar to Freud's notion of a city with memory, but one which is neurotic and nonproductive (see Sardello, 1982). 
Indeed, Rancho Santa Margarita is described as a utopian escape, a 'natural' haven from the sprawling suburbs and cities:

"For people who like small towns, the choice is getting smaller. Because in this age of growth the small town is disappearing. Merging with cities, and other towns in a phenomenon called sprawl. Urban sprawl.

Where can you go to escape ... without totally distancing yourself from all that the large city offers? Today, almost nowhere. Unless you can find a place as gifted by nature as Rancho Santa Margarita" (Santa Margarita Company, 1986b, page 5).

As this last quote suggests, however, "urban sprawl" is seen as an inevitable result of the "age of growth" and economic prosperity that Orange County has witnessed in recent years. In 1990, Orange County had the twenty-seventh largest GNP in the world (Morrison, 1990). The Orange County growth center, with its "transaction-intensive economies, deeply segmented labor markets and regressive labor relations, and high-technology production systems", is economically dependent upon its historical and geographical proximity to Los Angeles, as Scott (1988, page 160) has well documented. And yet, the story of present and future economic development is positioned in contrast to Los Angeles. ${ }^{(16)}$

\subsection{A hierarchy of place: social distance}

According to Image of Success, a regional socioeconomic profile available only to potential Orange County investors, "Orange County is quite distinguishable from its Los Angeles neighbors ... for one overwhelming reason: the level of affluence enjoyed by its residents" (Orange County Register 1989, page 5).(17) In Image of Success, Orange County residents are compared with their Los Angeleno counterparts in order to give business an idea of where investment returns will be highest in the future. The 'typical' Orange County resident tends to be younger, better educated, is more likely to work in a professional, managerial, or technical occupation, and has a higher annual mean income than does the typical Los Angeleno. There is also a higher rate of homeownership in Orange County, even though land values and mortgages are high and continue to rise (Wright and Riave, 1986). Moreover, more than $90 \%$ of Orange County residents are white; in particular, when compared with Los Angeles, Orange County has very few African-American residents $1.8 \%$ compared with $12.4 \%$ ). In Image of Success it is suggested that the creation of a social hierarchy has also constituted a hierarchy of place. The 'American dream' is represented as no longer available in Los Angeles, but is present in the future of Orange County.

The formation of such high and low categories, according to Stallybrass and White (1986), are linked to the process through which the low troubles the high. A look at residential surveys of Orange County seems to confirm this; people living there are concerned about the decline of 'quality of life' in their communities. For example, in the 1990 Orange County Annual Survey it was stated that six in ten residents said their commute had worsened, almost $90 \%$ of surveyed residents were worried about air pollution, and $57 \%$ mentioned that traffic and growth are the two most

(16) Recent literature about the 'other' has focused upon the establishment of binary categories, such as 'civilized' and 'savage', as an expression of power relations between 'colonizer' and 'colonized'. A history of the power relations between Los Angeles and Orange County along these lines would be an interesting one (but is beyond the scope of this paper) because the roles of 'colonizer' and 'colonized' may have been reversed in the recent past (see Davis, 1990; Scott, 1988; Till, 1991).

(17) Image of Success is published by the Orange County Register. The marketing director of The Irvine Company informed me of this publication. 
important problems in Orange County (Sullivan, 1990).(18) Results from another poll indicated that Orange County residents wanted to live in a "safe, crime-free environment" (Scheer, 1989b, page 5). These anxieties about smog, traffic, uncontrolled growth, violence, and so on, have been manipulated by Orange County corporate planners to create the symbolic images of towns and villages which are described as anything but the Los Angeles 'other'.

At the same time, however, these same residential concerns have resulted in a popular movement which has been particularly problematic for Orange County developers-slow-growth constituencies. In 1988, for example, land developers, the building industry, and business leaders (including bank executives of Security Pacific and Wells Fargo, and employers such as Rockwell International and McDonnellDouglas) spent over \$2 million to defeat slow-growth Measure A. This measure was an Orange County ballot proposal on 8 June 1988 and labelled 'slow-growth' because it would have restricted most of the development in the southern Orange County area (see Davis, 1990; Haas, 1988a; 1988b). Had this measure passed, it would have slowed or stopped the completion of Rancho Santa Margarita (Haas, 1988b). As this example illustrates, the real or imagined fears of 'other' places such as Los Angeles may not trouble only the 'high'; because these anxieties come from real people, they may, in turn, create problems for local developers. Ironically, although large corporate developers may attempt to reinforce these social categories of high and low through promotional materials, their images may inadvertently support local slow-growth movements. It is important to note, however, that homeowners associations and other slow-growth constituencies have also used residential concerns to promote social and spatial fragmentation in southern California, as Davis (1990) has illustrated.

Orange County corporate planners focus on these residential troubles for other reasons. The Santa Margarita Company, like the corporate planner The Irvine Company, targets its promotional materials to persons already living in Orange County (interviews with S Kellenburg, Senior Vice President, PBR, November 1989; M Horst, Senior Vice President, PBR, March 1990; R Watson, Vice President, The Irvine Company, November 1989). Statistics for Rancho Santa Margarita support this: in $1988,80 \%$ of the urban village residents relocated from within Orange County (El Campanero 1988). Implicit to the stories and images presented by the Santa Margarita Company are assumptions based upon demographic data analyses of the 'life-styles' of current residents living in particular areas. ${ }^{(19)}$ Specifically, the Santa Margarita Company used the Claritas geodemographic system for their initial market-feasibility analysis for Rancho Santa Margarita by analyzing Orange County consumer data (interview with M Horst, Senior Vice President, PBR, March 1990). Geodemography blends demographic information with geographic consumer information; it is assumed that households with the same zip code have similar life-styles. In addition to demographic data obtained from the US Census, Claritas uses spatially coded consumer information to divide the USA into forty life-style segments according to a 'ZIP quality' scale of affluence (Weiss Michael, 1989). For example, $19.3 \%$ of the Orange County population is defined by Claritas as belonging to the 'new beginnings' life-style cluster (divorced Americans looking for

(18) The Orange County Annual Survey is released annually "with much media fan-fare" by Baldassare and Associates (Sullivan, 1990). Baldassare is a social ecologist at the University of California, Irvine, CA.

(19) These data systems include 'psychographics' (developed by the firm Yankelovich, Skelly and White, who measured the effects of social trends on consumer habits in the early 1970s), 'VALS' (Values and Lifestyles System, developed by SRI International in the late 1970s), and 'geodemography'. (See Fox, 1985; Klein, 1989; Till, 1991, chapter 5; Weiss Michael, 1989). 
new jobs and life-styles), $8 \%$ to the 'money and brains' cluster (the nation's second highest socioeconomic rank, with childless couples and 'upscale' singles), and $1.3 \%$ to the 'blue blood estates' cluster (the highest life-style segment in America) (compare Klein, 1989). ${ }^{(20)}$

At Rancho Santa Margarita, "you are where you live" (compare Klein, 1989); the urban village life-style not only defines where you live, it defines who you are according to socioeconomic status and race. The corporate planners for Rancho Santa Margarita, as well as for other planned communities in southern Orange County, use perceived regional troubles along with geodemographic analyses to sell their product to specific markets. In doing so, they reinforce social and spatial divisions by presenting these 'differences' as historically, socially, and territorially inevitable.

\subsection{The 'other' in Orange County}

These social and spatial divisions are not as clear-cut as they may first appear.

The Los Angeles 'other' also exists within Orange County itself. The images of the small town are actually produced by corporate planners for the newer, master-planned communities in the south. To persons not living in this area, the boundary between north and south Orange County may seem to be an arbitrary line on a map. But for residents, businesses, land developers, and public officials this boundary represents both a cultural and a territorial identity associated with security and profit (for a discussion of territoriality, see Sack, 1986).

The line separating north from south represents a social, political, and visual division which has been historically moving south and continues to be challenged. As Dodson (1989a, page 1) explains, "no one disputes there is a North and South Orange County. But the location of our own Mason-Dixon line is open to debate". The appeal toward an historic antebellum border separating the life-styles of the urban north from the rural south is actually quite appropriate. Space has become a means by which people are classified as rich or poor, homeowners or homeless, white or colored.

This territorial boundary, for example, has come to symbolize economic stability and profit for corporate planners and homebuyers alike; "the majority of sales are occurring in the southern part of the county, with its more affordable housing and better quality of life" (Beaudette, 1987, page 7). ${ }^{(21)}$ However, the "more affordable housing' in southern Orange County are town houses which, on average, sold for $\$ 120000$ in 1986 (Beaudette, 1987; Campbell, 1990b). ${ }^{(22)}$ Indeed, residents in the south favor town houses and condominium developments because they are most likely to be found in "planned communities which have a uniform appearance and community codes and regulations-a preference that grows with incomes"

(20) People that fall in the 'new beginnings' category are in the age group 18-34, childless, and in lower-level white-collar and clerical occupations. 'Money and brains' people live in "swank, shipshape townhouses, apartments and condos". These people are considered to be "sophisticated consumers of adult luxuries", including apparel, restaurants, and travel (Weiss Michael, 1989).

(21) According to Marc Weiss (1987), a planned community is considered a safer investment for homebuyers and more profitable for land developers because neighboring land uses are fixed, and services and other amenities are provided by the land developer as part of the negotiation process with the local government agencies.

(22) Because median prices for homes in Orange County have been much higher than national or California state averages since the 1980s (the median price for a new home in Orange County was $\$ 245262$ in 1989 ), town houses are considered to be the most affordable housing type in Orange County. In 1990, only $3.4 \%$ of Orange County's 180000 apartments were rented for less than $\$ 500$ per month. According to one estimate, a future Orange County resident needs an annual income of $\$ 30040$ to rent an average apartment, or an income of $\$ 63180$ to buy a town house (Campbell, 1990b; also see Campbell, 1990a; Orange County Pegister 1990a). 
(Dodson, 1989b, page 1). These same residents, however, feel that crime would increase and property values decrease if low-cost housing were built in their neighborhoods, even though they are aware that most low-income and middleincome families have difficulty in paying current housing prices.

When the code words 'affordable housing' are mentioned, people in Orange County "expect to see junked cars and people selling dope" (Terner, quoted in Campbell, 1990b, page 11). It is not surprising that the Santa Margarita Company uses the term 'entry-level housing' rather than 'affordable housing' to describe the housing units that are required by Orange County's Inclusionary Housing Program (IHP, totalling $26.3 \%$ of Rancho Santa Margarita units) (correspondence with D Gaynor, Public Relations Director, Santa Margarita Company).(23) Those families that cannot afford to buy homes or rent units, rent space in Orange County's 'invisible slums', garages or single-room apartments that are shared with other families and that tend to be located in the north (Campbell, 1990b). According to Davis (1990, page 209), "since there is virtually no low-income housing between the Santa Ana barrio and East San Diego (a ninety-mile distance) thousands of day-laborers and their families-Spanish speaking Oakies of the 1980s-are forced to live furtively in hillside dugouts and impromptu bush camps, often within sight of million-dollar tract homes whose owners now want the 'immigrant blight' removed".

Living in the south means that you can purchase a community identity that is visibly distinct from that of the north-be it northern Orange County or Los Angeles. "It's a style, both in development and living, that distinguishes the south from the north" (Baldassare, quoted in Dodson, 1989a, page 7). To Orange County developers and to some residents, the difference between south and north is the difference between their vision of the 'urban village' on the one hand and the 'dangerous city' on the other. The one is small, clean, green, and planned, where safety, open spaces, and people-oriented places are located. The other is big, polluted, dark, and chaotic, where crime, homeless spaces, and ghettos predominate.

\section{Closing remarks}

In this paper, I have attempted to show that neotraditionalists have invented traditions such as family histories and have 'preserved' landscapes to provide a sense of community identity for a town or village as well as to legitimate their own status as experts. Moreover, because these texts are targeted toward specific regional markets, they also reflect and reinforce the "shared experiences, perceptions, and attitudes of the segmented audience" (Leiss and Jhally, 1986, page 151). In a way, they are like popular songs: copies without originals, "texts whose popularity depends less on innovation or imagination than upon a sense of familiarity conducive to immediate audience appropriation" (after F Jameson, in Lipsitz, 1990, page 14). The success of the small-town identity that planners would like to foster depends upon the familiarity of the potential homebuyer with these regional images.

Although I have criticized the neotraditional movement, I have not discussed how the residents themselves view the intended messages of these promotional materials. Do residents appropriate the neotraditional symbols for their own purposes? Do they in any way contest these notions of community identity?

(23) Government agencies in Orange County are also responsible for the lack of low-income housing units. Under the IHP developers must provide a certain percentage of total housing to "people who meet the County's identified income qualifications" (correspondence with D Gaynor, Public Relations Director, Santa Margarita Company). These qualifications are based upon the County median income at the time of sale. But because the median Orange County family income is so high (\$49916 in 1989), an income considered substantial elsewhere would still qualify a family for 'affordable' housing under Orange County's IHP. 
A cultural ethnography of neotraditional towns would be an appropriate follow-up study to this paper, a project which I plan to pursue when Rancho Santa Margarita is completed. At this point, I can only offer a superficial summary based upon a handful of discussions I have had with residents living at Rancho Santa Margarita during Spring 1990. All the residents with whom I spoke said that they liked living in the urban village, but their responses (except for those of children) were guarded, even suspicious; they did not seem to understand why anyone would ask them these questions. When I asked them why they moved, the overwhelming reason given was that they were looking for a 'safe' place to live and raise a family, a neighborhood with no surprises. One woman who moved from El Cajon (a city in northeast San Diego County located next to the town where I grew up) explained that she was glad to leave El Cajon because it had become "disorganized", "cluttered", and "ugly". She said she was happy to find a place that was orderly and predictable, but, she added, "you have to pay for it-and it's not cheap!". The journalist, Guterson, found similar responses from residents of the master-planned community Green Valley, in Las Vegas, NV. One resident moved to Green Valley from southern California because "even the good neighborhoods there aren't good anymore. You don't feel safe in L.A." (quoted in Guterson, 1992, page 62). These responses suggest that residents identify with the neotraditional texts and images found in promotional materials.

It is important to note, however, that the invented traditions I have outlined in this paper are intended to mean different things for these residents and for the planning experts themselves. When situated within the cultural context of the planning community, the 'revolutionary visions' of the neotraditionalists legitimate their status within the profession. For example, the neotraditionalists have created their own planning genealogy, one which highlights their position within the planning community as historically inevitable. Their self-proclaimed 'gurus', or 'fathers', date back to the early 20th century, and include planners such as Elbert Peets, Raymond Unwin, and John Nolen, as well as contemporary experts such as European architectural theorist Leon Krier and urban-design professor Christopher Alexander (Knack, 1989). With the proclamation of the 'second coming of the small town', neotraditionalists also claim to have reinvented the concepts of the 'urban village' and 'new town' for the American professional planning community. Although these planning 'traditions' date back to Ebenezer Howard's Garden Cities at the turn of this century, and more recently, to Jane Jacobs's urban villages of the 1960 s, the neotraditional towns and villages of the 1980 s and 1990 s do not reflect the socialist and utopian ideologies of their predecessors. Yet the recent 'historical' articles published in various planning journals about new towns such as Columbia, MD, built thirty years ago, and the Greenbelt towns of the 1930s, established during the 'new-deal' era, tend to support the neotraditionalist claim to authenticity (for example, see Bookout, 1987; Davis P, 1987; Tennenbaum, 1990). These stories about towns and villages, and about the neotraditional planning 'gurus', can also be seen as attempts to establish a sense of identity and historical continuity within the professional planning community itself.

This neotraditional image of continuity with the past lends false credibility to the notion of a coherent professional planning community. As Abbott and Adler (1989, page 467) explain, "since planners work within an imperfectly delimited profession and discipline, the argument goes, history has an important function in forming a group identity". Not surprisingly, these claims to historical stability occur at a time of perceived crisis in the profession. Certain authors have recently argued that planners no longer have a vision or sense of idealism founded in public values because of their changed relationship to private firms and large government agencies. 
According to Brooks (1988, page 241), "the profession needs a new generation of visionaries, people who dream of a better world, and are capable of designing the means to attain it". The literature on this theme is enormous, and includes, Boyer, 1983; Brooks, 1988; Marcuse, 1989; Teitz, 1989; Weiss Marc, 1989.

In fact, many observers believe the neotraditionalists to be the new generation of planning visionaries. For example, in Orange County and elsewhere, the urban village concept continues to be applauded for its provision of 'affordable housing', as well as for its "spirit of reform. A sprawling city is trying to coax its residents into closer-knit neighborhoods where people of different races and incomes will live near each other and where the proximity of offices, stores and parks will help discourage the use of automobiles" (Clifford, 1989b, page A1). As I have argued, however, it is important to recognize the shadow lurking behind these small-town images-a reactionary fear of the 'other' which neotraditionalists manipulate to sell a product. Far from integrating people of various races and incomes, their promotional materials, marketing analyses, and design guidelines reinforce homogeneity.

Although the stated goal of urban villages and neotraditional towns is to return the 'bonds of authentic community' back to American society, whenever this notion of community conflicts with the notion of 'community as commodity' the latter notion prevails. One story in the Rancho Santa Margarita community newsletter, El Campanero: The Bellringer, underscores this point. In 1989, residents of an enclave installed a bell and a sign declaring their cul-de-sac to be 'Madronaville'. When a resident wanted to have a neighborhood gathering, he or she would ring the bell; people would barbecue in the street, socialize, play football or baseball, and communally watch the children. But, because these additions did not meet regulations, they were taken down and replaced "with another bell, Pacific Bell" (Rule, 1989).(24)

The Madronaville story reminds us that consumers are not passive receivers of information but are real people with ideas. And some of these people may want to participate in the construction of their community. Yet because neotraditionalists rigidly specify design guidelines which are based upon marketing data, their notion of community is "intrinsically static and disposed toward preserving and codifying what already exists" (Shirvani, 1988, page 4). Thus, consumers are not allowed to decide what their community should be because those decisions have already been made for them by the 'experts'.

Places and communities are not static objects 'out there' but are "felt centers of meaning" created by individuals (Tuan, 1977). Even though some neotraditionalists may be trying to improve the ways in which people live, their normative notions of authentic community are eventually translated into master plans. Community becomes numerically codified in terms of the methods, data, guidelines, and regulations which run the production process. When viewed from the expert position, community is seen as a product obtainable through the efforts of a group of professionals. Consequently, the neotraditional small-town 'vision' is contradictory and self-subversive. The traditions invented by neotraditionalists not only promote an exclusionary sense of social cohesion and community identity, they ultimately validate a system which

(24) At Rancho Santa Margarita, residents must adhere to the state-mandated Covenants, Conditions, and Restrictions of the Rancho Santa Margarita Landscape and Recreation Corporation (SAMLARC). These regulations concern possible residential changes to the units, such as front-yard landscaping, house-color selection, room additions, and anything altering the exterior of any building. The use of the color purple, for example, requires the permission of a neighborhood architectural standards committee. Moreover, to enjoy the open spaces and recreational facilities at Rancho Santa Margarita, each houslehold must pay a mandatory fee to SAMLARC, which is subject to change (in 1990 the fee was \$34 a month) (Merit Property Management, 1986; see also Dodson, 1989b; Guterson, 1992). 
destroys the possibility of establishing the 'bonds of authentic community' in the first place.

Acknowledgments. I would like to thank Steven Vance and the Santa Margarita Company, in particular Diane Gaynor, for allowing me to reproduce copyrighted materials. My deepest appreciation is extended to Peter Jackson for his encouragement and editorial comments. Thanks also to Michael Curry, J Nicholas Entrikin, Clayton Lee, Yi-Fu Tuan, Bob Sack, David and Jennifer Fondiller, Michael Castellon, and two anonymous reviewers for their comments on earlier versions of this paper. I would also like to thank my family for their support. I am grateful to the Alexander von Humboldt Foundation for their financial support at the time this paper was written.

\section{References}

Abbot C, Adler S, 1989, "Historical analysis as a planning tool" Journal of the American Planning Association 55 467-473

Beaudette A, 1987, "The L.A. Basin today: Orange County" Urban Land September, pp 7-9

Boatright M, 1957, "The Western bad man as hero" Mesquite and Willow publication xxvii

(Texas Folklore Society, Dallas, TX)

Bookout L, 1987, “Greenbelt, Maryland: a 'new' town turns 50" Urban Land August, pp 7-11

Boyer C, 1983 Dreaming the Rational City: The Myth of American City Planning (MIT Press, Cambridge, MA)

Bressi T, 1992, "The neo-traditional revolution" Utne Reader 51 101-104

Brooks M, 1988, "Four critical junctures in the history of the urban planning profession" Journal of the American Planning Association 54 241-248

Burrows T, 1989, "New traditionalism in suburban design" APA Zoning News June, pp 1-2

Campbell R, 1990a, "Land squeeze: prices for parcels jack up housing costs" Orange County Register 11 March, pp M3, M5-M7

Campbell R, 1990b, "Moving out of reach: prices spoil dream to own home in OC" Orange County Register 11 March, pp M1, M9-M11

Clifford F, 1989a, "The urban village designs of tomorrow" The Los Angeles Times: Orange County Edition 15 December, page A1

Clifford F, 1989b, "Southland's past may be part of its future" The Los Angeles Times: Orange County Edition 25 December, pp A1, A38

Clifford J, 1988 The Predicament of Culture: Twentieth-century Ethnography, Literature, and Art (Harvard University Press, Cambridge, MA)

Clifford J, Marcus G (Eds), 1986 Writing Culture: The Poetics and Politics of Ethnography (University of California Press, Berkeley, CA)

Cramer E (Ed.), 1988 A Hundred Years of Yesterdays: A Centennial History of the People of Orange County and their Communities Orange County Register, 625 North Grand Avenue, Santa Ana, CA 92711

Davis M, 1990 City of Quartz: Excavating the Future in Los Angeles (Verso, London)

Davis P, 1987, "Columbia, Maryland: zero to 68,000 in 20 years : Rouse's dream is now a real city" Urban Land November, pp 2-7

Dodson M, 1989a, "The great divide: where is the County's 'Mason-Dixon' line? Start at Costa Mesa Freeway and meander south" The Los Angeles Times: Orange County Edition 27 August, part II, pp 1, 7

Dodson M, 1989b, "Future 'urban center' rises in South County" The Los Angeles Times: Orange County Edition 30 August, part I, page 1

Dorst J, 1989 The Written Suburb: An American Site, an Ethnographic Dilemma (University of Pennsylvania Press, Philadelphia, PA)

Duany A, Plater-Zyberk E, 1992, "The second coming of the small town" Utne Reader 51 97-100

El Campanero 1988, "Did you know?" El Campanero: The Bellringer. A Newsletter for Rancho Santa Margarita 1(4) 1

Fabian J, 1983 Time and the Other: How Anthropology Makes its Objects (Columbia University Press, New York)

Fox W, 1985, "Demographics giving way to psychographics" Boston Globe 6 March, pp A93, A99

Gerloff R, 1992, "Rediscovering the village" Utne Reader 51 93-96

Guterson D, 1992, "No place like home: on the manicured streets of a master-planned community" Harper's November, pp 55-64 
Haas J, 1988a, "Anti- versus pro-growth forces in southern California: a ballot box battle" Urban Land October, pages 2-5

Haas J, 1988b, "The defeat of a slow-growth ballot proposal" Urban Land October, page 3

Hobsbawm E, 1983, "Introduction: inventing traditions", in The Invention of Tradition

Eds E Hobsbawm, T Ranger (Cambridge University Press, Cambridge) pp 1-14

Hobsbawm E, Ranger T (Eds), 1983 The Invention of Tradition (Cambridge University Press, Cambridge)

Hunt L (Ed.), 1989 The New Cultural History (University of California Press, Berkeley, CA)

Klein D, 1989, "You are where you live: neighborhoods by the numbers: how ZIP-codes can pigeonhole people like widgets in a digit factory" The Los Angeles Times 16 April, part VI, pp $1,8,9$

Knack R, 1989, "Repent, ye sinners, repent" Planning August, pp 4-13

Langdon P, 1988, "A good place to live" Atlantic Monthly March, pp 39-60

Leiss W, Jhally S, 1986 Social Communication in Advertising: Persons, Products, and Images of Well-being (Methuen, New York)

Leslie D, 1992, "Advertising, femininity and place", paper delivered at the annual Association of American Geographers conference, 21 April, San Diego, CA; copy available from

D Leslie, Department of Geography, University of British Columbia, Vancouver

Lipsitz G, 1986, "The meaning of memory: family, class, and ethnicity in early network television programs" Cultural Anthropology 1 355-381

Lipsitz G, 1990 Time Passages: Collective Memory and American Popular Culture (University of Minnesota Press, Minneapolis, MN)

Lockwood C, Leinberger C, 1988, "LA comes of age" Atlantic Monthly 261 31-55

Lowe M, 1992, "How to make cities more humane" Utne Reader 51 104-106

Lowenthal D, 1985 The Past is a Foreign Country (Cambridge University Press, Cambridge)

Marcuse P, 1989, "Who/what decides what planners do?" Journal of the American Planning Association 55 79-81

Merit Property Management, 1986, "14 things you should know about maintenance corporations", brochure printed for Rancho Santa Margarita residents; copy available from Merit Property Management Inc., 24422 Avenida de la Carlota, Suite 460, Laguna Hills, CA 92653

Morris R, 1989, "Santa Barbara style" Westways 81(11) 30-33

Morrison P, 1990, "L.A. vs. O.C.: just how different are they, anyway? Now the truth can be told" Los Angeles Times Magazine 17 June, pp 10-18, 23-25, 37-39

Namie L, 1942, "Symmetry and repetition", in Conflicts (Macmillan, London)

OCHC, 1988, "Orange County Centennial historical map", Orange County Historical Commission and the Automobile Club (AAA) of Southern California (Anderson Lithographs, Los Angeles, CA)

Orange County Register 625 North Grand Avenue, Santa Ana, CA 92711 1988/89 The Answer Book: Centennial Edition

1989 A Profile of Orange County: Image of Success: Southern California's Richest Market 1990, "Tax-free bonds: funds built luxury apartments, not low-income housing" 11 March, pp M2-M4

People Weekly 1990, "Banishing cookie-cutter 'burbs'” People Weekly Extra Spring, pp 72-74

Perlman M, 1988 Imaginal Memory and the Place of Hiroshima (State University of New York Press, New York)

Rule A, 1989, "Madronaville" El Campanero: The Bellringer. A Newsletter for Rancho Santa Margarita 2(4) 6

Sack R, 1986 Human Territoriality: Its Theory and History (Cambridge University Press, Cambridge)

Sack R, 1988, "The consumer's world: place as context" Annals of the Association of American Geographers 78 642-664

Santa Margarita Company, 30211 Avenida de las Banderas, Rancho Santa Margarita, CA 92688 1985 Rancho Mission Viejo: Where History is Still Happening (Special Rancho Santa Margarita edition, 1769-1986) 1 1-4

1986a Trabuco Mesa: Where History Found a Home: Rancho Santa Margarita Messenger grand opening keepsake edition 1 1-4

1986b Rancho Santa Margarita Community Brochure

1988 Rancho Santa Margarita Community Brochure

1989a, "The vision behind Rancho Santa Margarita" Rancho Santa Margarita Community

Brochure inside cover 
1989b, "Santa Margarita Company Fact Sheet"

1991 Rancho Santa Margarita Community Brochure

1992 Rancho Mission Viejo: Where History is Still Happening 1 1-4

Sardello R, 1982, "City as metaphor, city as mystery" Spring 1 95-111

Scheer R, 1989a, "A frontier dream comes of age for Orange County" The Los Angeles Times 4 June, pp 1, 26-28

Scheer R, 1989b, "Orange County-home of the happy and optimistic" The Los Angeles Times 5 June, pp 1, 5, 26-27

Scott A, 1988 Metropolis: From Division of Labor to Urban Form (University of California Press, Berkeley, CA)

Shirvani H, 1988, "Architecture versus franchised design" Urban Design and Preservation Quarterly $11(2 / 3) 2-8$

Silverman D, 1986 Selling Culture: Bloomingdale's, Diana Vreeland, and the New Aristocracy of Taste in Reagan's America (Pantheon Books, New York)

Smith R, 1989, "Where have you been?" Planning October, page 33

Stallybrass P, White A, 1986 The Politics and Poetics of Transgression (Cornell University Press, Ithaca, NY)

Sullivan V, 1990, "A chronicle of our discontent" U.C. Focus 4(4) 7; copy available from Office of University Relations, 300 Lakeside Drive, 22nd floor, Oakland, CA 94612-3550

Tatum R, 1988 Inventing Billy the Kid (University of New Mexico Press, Albuquerque, NM)

Teitz M, 1989, "The uses and misuses of history" Journal of the American Planning Association $5581-82$

Tennenbaum J, 1990, "Hail Columbia" Planning (May) 16-17

Till K, 1991, "Expert conceptions of place and community: the planner's vision of Rancho Santa Margarita", unpublished MA thesis, Department of Geography, University of California, Los Angeles, CA

Tuan Y-F, 1977 Space and Place: The Perspective of Experience (University of Minnesota Press, Minneapolis, MN)

Tuan Y-F, 1980, "Rootedness versus sense of place" Landscape 24 3-8

Weiss Marc, 1989, "Planning history: what story? What meaning? What future?" Journal of the American Planning Association 55 82-84

Weiss Michael, 1989 The Clustering of America (Harper and Row, New York)

Williamson J, 1978 Decoding Advertisements (Marion Boyars, London)

Wright T, Riave C, 1986, "The decline of Orange County's suburban oasis: regional problems in employment, housing, and transportation", unpublished manuscript, available from Fair Housing Council of Orange County, 1525 E. 17th Street, Suite E, Santa Ana, CA 92701

Wright W, 1975 Sixguns and Society: A Structural Study of the Western (University of California Press, Berkeley, CA)

Wynns J, 1989, "Lifestyles for Planet Earth" El Campanero: The Bellringer. A Newsletter for Rancho Santa Margarita 2(4) page 5

\section{Filmography}

Blade Runner 1982, Director Ridley Scott (Warner Bros, USA)

Grand Canyon 1991, Director Lawrence Kasdan (Twentieth Century Fox, USA)

L.A. Story 1991, Director Mick Jackson (Carolco Pictures, USA)

Scenes from a Mall 1991 Director Paul Mazursky (Touchstone Pictures, USA) 